\title{
The Effect of PhET-Assisted Problem Solving Method on Students' Critical Thinking skills
}

\author{
*Ni Nyoman Sri Putu Verawati, Hikmawati \\ Physics Education Department, Universitas Mataram, J1. Majapahit No.62, Mataram 83115, Indonesia \\ *Corresponding Author e-mail: veyra@unram.ac.id
}

Received: May 2021; Revised: June 2021; Published: June 2021

\begin{abstract}
This study aimed to determine the effect of PhET-assisted problem solving methods on students' critical thinking skills. This research is a quasi-experimental research with pretest posttest control group design. Sampling was done by simple random sampling technique, namely class XI IPA-1 as the experimental class and XI IPA-2 as the control class. The research was conducted in one of the senior high schools in Central Lombok - West Nusa Tenggara. The data analysis technique used is t-test using SPSS. The result of hypothesis testing is that the t-test value is less than 0.05. These results indicate that Ho is rejected and Ha is accepted. Based on the results of research and data analysis, it can be concluded that the PhET-assisted problem solving learning method affects students' critical thinking skills.
\end{abstract}

Keywords: Problem solving, PhET, critical thinking skills

How to Cite: Verawati, N., \& Hikmawati, H. (2021). The Effect of PhET-Assisted Problem Solving Method on Students' Critical Thinking skills. Prisma Sains : Jurnal Pengkajian Ilmu dan Pembelajaran Matematika dan IPA IKIP Mataram, 9(1), 136-140. doi:https://doi.org/10.33394/j-ps.v9i1.4001

https://doi.org/10.33394/j-ps.v9i1.4001

Copyright $(2021$, Verawati \& Hikmawati This is an open-access article under the CC-BY License.

\section{INTRODUCTION}

Education plays an important role in the progress and development of a country. Countries that are said to be developed can be seen from the increasing quality of education in the future. Therefore, the development of science, technology and the increasing needs of society need to be balanced with improving the quality of education (Prihatiningtyas et al., 2013). Physics is a branch of science. Physics is the result of human activities in the form of organized knowledge, ideas, and concepts about the natural surroundings obtained from a series of experiences through scientific processes (Assalam et al., 2020). Physics lessons are not enough to just study the product but emphasize how the product is obtained, both as a scientific process and the development of students' scientific attitudes. For that there must be appropriate innovative learning, not only apart from teacher-centered learning approaches and student-centered approaches (Prasetra, 2014).

One of the learnings that apply student centered is the problem solving learning method (Halimah et al., 2019). Problem solving learning methods become an important focus in learning physics, because the main goal of learning physics is to train students to become reliable problem solvers. Problem solving learning method is a learning concept that relates the material being taught to the problems faced daily. In this learning method, students are expected to be able to solve physics problems according to the understanding of each student based on the knowledge they already have. The learning process with problem solving takes place naturally in the form of student activities working and experiencing, not just transferring knowledge from teacher to student (Larkin et al., 1979). One of the interesting learning media to collaborate with problem solving learning is PhET (Physics Education Technology) simulation media. PhET simulation is a simulation created by the University of Colorado that contains physics learning simulations for the benefit of classroom teaching or 
individual study. PhET simulation emphasizes the relationship between real-life phenomena and the underlying science, supports an interactive and constructivist approach, provides feedback, and provides a creative workplace (Sari et al., 2018).

Mastery of physics material requires students' ability to think logically and critically, therefore the applied model should facilitate students' thinking activities. The emphasis that causes the weak quality of learning is rooted in the weakness of the learning process that does not encourage students to think critically (Prayogi et al., 2018). Critical thinking has become a very important part as one of the learning objectives, so that students are able to develop their critical thinking skills. However, it is a fact that most students do not understand the concept of critical thinking even though they unconsciously think critically in some ways when learning occurs (Wahyudi et al, 2018). It is believed that the conventional learning process that only relies on the lecture method cannot train critical thinking (Verawati et al., 2021). This method focuses on the role of the teacher more than the role of students who only listen, receive and record the material provided. This causes most students to be passive and less active in learning. So that students' critical thinking skills are not optimal. Learning that collaborates problem solving learning methods and PhET simulation media is expected to create an interesting learning atmosphere, make students more active, and increase students' motivation to understand physics so that it can help students improve students' critical thinking skills. This study was conducted to determine students' critical thinking skills between students who study with PhET-assisted problem solving learning methods and conventional learning. Specifically, the purpose of this study was to determine the effect of the PhET-assisted problem solving learning method on students' critical thinking skills.

\section{METHOD}

This study uses a quasi-experimental research type with the research design being a pretest-posttest control group design. Sampling was done by simple random sampling technique, namely class XI IPA-1 as the experimental class and XI IPA-2 as the control class. The research was carried out in one of the senior high schools in Central Lombok - West Nusa Tenggara.

The data analysis technique used in this research is descriptive analysis. The data obtained are described without giving special treatment to the research subjects and reported as they are. The results of the data description were obtained from the critical thinking ability test scores. Students' critical thinking skills were analyzed through critical thinking rubrics. The data obtained in this study is quantitative data, namely data about critical thinking ability test scores. To determine the level of students' critical thinking skills were analyzed descriptively. The category of critical thinking according to Prayogi \& Asy'ari (2013), where the conversion scale becomes four categories of critical thinking, namely very critical (81.25100), critical (62.50-80.25), less critical (43.75-61.50), and very less critical (25.00-42.75). The analysis of the difference in critical thinking skills between the experimental and control classes was carried out by statistical analysis, namely the t-test. As a prerequisite for the ttest, homogeneity and normality tests were carried out. Testing at a significance level of 0.05 .

\section{RESULTS AND DISCUSSION}

The results of the pre-test and post-test of the experimental class and control class students in this study are presented in Table 1.

Table 1. Descriptive analysis results

\begin{tabular}{lccccc}
\hline & $\mathrm{N}$ & Minimum & Maximum & Mean & Std. Deviation \\
\hline Pretest experiment & 21 & 25.00 & 57.50 & 36.66 & 8.15 \\
Postest experiment & 21 & 52.50 & 100.00 & 76.78 & 13.11 \\
Pretest control & 23 & 27.50 & 47.50 & 35.21 & 6.16 \\
Postest control & 23 & 50.00 & 82.50 & 61.08 & 9.93 \\
Valid N (listwise) & 21 & & & & \\
\hline
\end{tabular}


The students' pretest data were analyzed for variance to determine the homogeneity of students' prior knowledge. The results of the initial data calculation for the sample homogeneity test are presented in Table 2 .

Table 2. Homogeneity test results

\begin{tabular}{llcccc}
\hline & Levene Statistic & df1 & df2 & Sig. \\
\hline Pretest & Based on mean & 1.435 & 1 & 42 & .238 \\
& Based on median & 1.294 & 1 & 42 & .262 \\
& Based on median and with adjusted & 1.294 & 1 & 38.811 & .262 \\
df & 1.487 & 1 & 42 & .230 \\
\hline
\end{tabular}

Based on the results of the analysis presented in Table 2, it can be stated that the variance of the students' pretest data was homogeneous, because the value of Sig. (0.238) > 0.05. Parametric statistical tests have prerequisites to be carried out, namely the data must be normally distributed and test variance (homogeneity) if the number of research samples is less than 30. The data from the posttest results in the experimental and control classes were tested for distribution using the Kolmogorov-Smirnov test first to find out the data obtained were normally distributed or not. The results of the normality test are presented in Table 3.

Table 3. Normality test results

\begin{tabular}{llccc}
\hline \multirow{2}{*}{ Kelas } & \multicolumn{3}{c}{ Kolmogorov-Smirnov } \\
\cline { 3 - 5 } Posttest & Statistic & df & Sig. \\
\cline { 2 - 5 } & Pretest experiment & .126 & 21 & $.200^{*}$ \\
& Postest experiment & .081 & 21 & $.200^{*}$ \\
& Pretest control & .210 & 23 & .010 \\
& Postest control & .206 & 23 & .012 \\
\hline
\end{tabular}

Table 3 shows that the significance value of the experimental and control class posttest data is greater than 0.05 so it can be stated that the data is normally distributed. Statistical hypothesis testing in this study was conducted by t-test to determine the difference in student learning outcomes between the experimental class after learning using the PhET-assisted problem solving learning model and after conventional learning in the control class. Data on the results of testing the effect of PhET-assisted problem solving learning methods on students' critical thinking skills are presented in Table 4.

Table 4. Hypothesis test results

\begin{tabular}{llccc}
\hline & & \multicolumn{3}{c}{ t-test for Equality of Means } \\
\cline { 3 - 5 } & & $\mathrm{t}$ & $\mathrm{df}$ & Sig. (2-tailed) \\
\hline Posttest (exp-con) & Equal var. assum. & -11.907 & 40 & .000 \\
& Equal var. not assum. & -11.907 & 33.450 & .000 \\
\hline
\end{tabular}

Based on the test results as shown in Table 4, it is known that the value of Sig. (2tailed) posttest data (0.00) is smaller than the alpha test (0.05), so it can be stated that the PhET-assisted problem solving learning method affects students' critical thinking skills. These results indicate that $\mathrm{HO}$ is rejected and $\mathrm{Ha}$ is accepted. This means that there is a significant effect of using PhET-assisted problem solving learning methods on the students critical thinking skills.

Based on the results of hypothesis testing, it shows that there are differences in critical thinking skills between the experimental and control classes. Learning with the PhET-assisted problem solving method has a higher average score than the conventional method. This is in accordance with research from Sunni (2013) which revealed that learning with the PhETassisted problem solving method has better critical thinking skills than students who study with conventional learning. 
The problem solving method besides having several advantages, this method also has disadvantages, one of which is not effective if there are passive students. These weaknesses can be overcome by utilizing media that attracts students to be directly and actively involved in the process. The presence of learning media can have a positive influence on students. One of the interesting media is PhET simulation media. The main purpose of using PhET simulation media is to increase student involvement and can invite students' attention because it is designed in an attractive and easy-to-understand way so that students can try to explore or be actively involved.

Students' critical thinking skills can be improved by using problem solving learning methods in collaboration with the use of PhET simulations. In PhET simulation, it can provide fast feedback after various settings are made, so it is useful for students to improve their ability to make a causal relationship from an action taken during the setting. The results of the research data analysis that have been carried out show that there is a significant effect of using PhET-assisted problem solving learning methods on students' critical thinking skills. This means that using the PhET-assisted problem solving learning method can have a positive influence on students' critical thinking skills.

\section{CONCLUSION}

Based on the results of research and data analysis, it can be concluded that there is an effect of using PhET-assisted problem solving methods on students' critical thinking skills.

\section{RECOMMENDATION}

The implication of the results of this study is that this method can be applied for the purpose of training students' critical thinking.

\section{ACKNOWLEDGMENT}

This research received no specific grant from any funding agency in the public,commercial, or not-for-profit sectors.

\section{REFERENCES}

Assalam, I.R., Sriyono \& Nurhidayati. (2020). Pengembangan lembar kegiatan peserta didik berbasis group investigation untuk menguatkan karakter peserta didik dalam memecahkan masalah. JIPS: Jurnal Inovasi Pendidikan Sains, 1(2), 33-41.

Halimah, H., Sutrio, S., \& Verawati, N.N.S.P. (2019). The effect of double-loop problemsolving models on students' critical thinking ability, Prisma Sains: Jurnal Pengkajian Ilmu dan Pembelajaran Matematika dan IPA, 7(2), 160-168.

Larkin, Jill, H. \& Reif, F. (1979). Understanding and teaching problem-solving in physics. European Journal of Science Education, 1(2), 191-203.

Prasetya, S.P. (2014). Memfasiltasi pembelajaran berpusat pada siswa. Jurnal Geografi, 12(1), 1-12.

Prayogi, S. \& Asy'ari, M. (2013). Implementasi model PBL (Problem Based Learning) untuk meningkatkan hasil belajar dan kemampuan berpikir kritis siswa. Prisma Sains: Jurnal Pengkajian Ilmu dan Pembelajaran Matematika dan IPA, 1(1), 80-88.

Prayogi, S., Yuanita, L, \& Wasis. (2018). Critical inquiry based learning: A model of learning to promote critical thinking among prospective teachers of physic. Journal of Turkish Science Education 15 43-56.

Prihatiningtyas, S., Prastowo, T., \& Jatmiko, B. (2013). Implementasi simulasi PhET dan kit sederhana untuk mengajarkan keterampilan psikomotor siswa pada pokok bahasan alat optik. Jurnal Pendidikan IPA Indonesia, 2(1), 18-22.

Sari, A.S.D., Prahani, B.K., Munasir, \& Jatmiko, B. (2018). The improvement of students physics problem solving skills through the implementation of PO2E2W learning model assisted PhET media. Journal of Physics: Conference Series, 1108, 1-6. 
Verawati, N.N.S.P., Hikmawati, \& Prayogi, S. (2021). The Effectiveness of reflective-inquiry learning model to improve preservice-teachers' critical thinking ability viewed from cognitive style. J. Phys.: Conf. Ser. 1747, 1-7.

Wahyudi, Verawati, N.N.S.P., Ayub, S. \& Prayogi, S. (2018). Development of inquirycreative-process learning model to promote critical thinking ability of physics prospective teachers J. Phys.: Conf. Ser. 1108, 1-7. 